\title{
Dois elos da mesma corrente: os rituais da Corrida do Imbu e da Penitência entre os Pankararu
}

\author{
Priscila Matta
}

resumo Este artigo pretende contribuir para o entendimento do sistema ritual Pankararu, principalmente a Corrida do Imbu e a Penitência, rituais cíclicos, realizados em um mesmo período temporal. $\mathrm{O}$ estudo foi direcionado à compreensão da relação entre os humanos e os sobre-humanos, o sistema de prestaçóes e a rede de cooperação e agressão que envolve este universo. Os mecanismos de comunicação e os vínculos estabelecidos com o mundo sobrenatural, baseados no sistema de promessas e pedidos, relativos principalmente à cura de doenças, são os elementos cotidianos de mediação dessa relação. Os Pankararu encontram-se na região do submédio São Francisco, estado de Pernambuco, e na Grande São Paulo, e estão em processo de migração desde a década de 1950 . São um povo que recebe a qualificação de aculturados e que passou por imperativas relaçóes de contato, intercasamentos com outros grupos e perda da língua materna.

palavras-chave Ritual. Índios no Nordeste brasileiro. Cosmologia. Pankararu. Etnologia indígena.

Este artigo $^{1}$ apresenta os rituais da Corrida do Imbu e da Penitência entre os Pankararu. Estes rituais, realizados anualmente entre os meses de fevereiro e março ${ }^{2}$, estão relacionados à cosmologia pankararu e ao sistema xamânico. Através da Corrida do Imbu e da Penitência, de promessas feitas aos seres sobre-humanos, da manifestação de doenças e respectivas curas é estabelecida uma rede de sociabilidade e de reciprocidade que envolve prestações e contraprestações entre humanos e sobre-humanos.
A Corrida do Imbu, ritual de grande expressão entre os Pankararu, está ligada aos encantados, entidades consideradas "vivas", cuja gênese remonta a um tempo mítico e se manifestam por meio de praiás - vestimentas e máscaras rituais. $\mathrm{Na}$ Penitência, as relações são com os mortos e com a Santa Cruz. Os penitentes, seguindo uma sequência ordenada, visitam cruzes de mortos fincadas em determinadas aldeias. Aos encantados e à Santa Cruz são atribuídos poderes de cura. Os rituais e as promessas, relacionadas à cura de doenças e a pedidos de diversas ordens, são veículos para os humanos estabelecerem contatos com os seres sobre-humanos. Em contrapartida à cura de doenças e realização de pedidos há o oferecimento de dádivas aos encantados e à Santa Cruz em momentos rituais.

Os Pankararu são encontrados no sertão de Pernambuco, região do submédio São Francisco, e em diversas localidades da cidade de São Paulo e da Grande São Paulo ${ }^{3}$. Em Pernambuco, estão distribuídos em dezesseis aldeias que somam cerca de 6.000 habitantes; na regiáo metropolitana de São Paulo, são entre 1.200 e 1.500 Pankararu, concentrados especialmente na favela do Real Parque, Zona Sul; nos bairros Madalena e Jardim Elba, Zona Leste da cidade ${ }^{4}$.

Este artigo aborda as relaçôes instituídas pela Corrida do Imbu e pela Penitência. Aquela por ser expressão significativa da cosmologia pankararu, e esta última, ritual de menor porte, por apresentar elementos e relaçóes similares à Corrida do Imbu e recriar o sistema ritual em sua interlocução com os eventos e a história. A 
Corrida do Imbu e a Penitência ocorrem nas aldeias em Pernambuco.

A intenção é abordar a lógica do sistema ritual pankararu, fonte de produção de significados a partir dos quais o grupo e os indivíduos organizam sua conduta, e revelar as redes de sociabilidade e de prestaçóes por meio do estabelecimento de vínculos entre os humanos, e entre os humanos e sobre-humanos, e não apresentar a etnografia de todos os rituais praticados pelo grupo. $\mathrm{O}$ sistema ritual pankararu abarca ritos públicos e privados.

Os Pankararu passaram por intensos contatos, sendo alvo de uma política de miscigenação, conversão e extinção, e foram considerados em muitos momentos como "ex-índios", mas lutaram para serem reconhecidos e valorizados como índios. Casos como esse fornecem pistas para a compreensão das transformações sofridas pelas sociedades ameríndias.

\section{A Corrida do Imbu}

A Corrida do $\mathrm{Imbu}^{5}$ é um rito de calendário que anuncia as condiçóes da colheita e indica o presságio da vida para o ano que entra. $\mathrm{O}$ principal momento da cerimônia da Corrida do Imbu é no começo da estação chuvosa, primeiros meses do ano, período de curta duração na caatinga $^{6}$, bioma com paisagem normalmente árida e índice pluviométrico baixo. Com as primeiras chuvas também se inicia o período de plantio.

A Corrida do Imbu acontece nas aldeias Brejo dos Padres e Serrinha. Brejo dos Padres é uma localidade central em termos populacionais, políticos e de oferta de serviços, além de ser um antigo local de moradia.

A parte principal do ritual estende-se por quatro semanas, tendo início no final de semana do domingo do Entrudo ${ }^{7}$ - dia do mela-mela, mela de lama e de giz branco, denominado toá, ou domingo de Carnaval, termos esses empregados pelos Pankararu - e encerrando-se com a "Saída do Mestre Guia", quatro finais de semana depois.

É um ritual constituído, em grande parte, por cerimônias públicas em que celebram a participação de todo o panteão de encantados ligados aos Pankararu. É um importante momento que marca anualmente a vida dos Pankararu. Nas cerimônias públicas, a participação está aberta aos Pankararu, aos encantados e aos de fora do grupo, que atuam mais como espectadores. A Corrida do Imbu funda a relação de reciprocidade entre os humanos e os seres sobre-humanos. Acontece em etapas ordenadas compostas por músicas, cantorias, danças rituais, oferta de comidas e bebidas, sendo que a força central está nas máscaras rituais denominadas praiás.

Os encantados são elementos centrais da Corrida do Imbu. São considerados pelos Pankararu como "entidades vivas" e estão ordenados segundo uma hierarquia. Sob o comando de todos os encantados está o Mestre Guia, encantado regido por uma entidade que denominam Deus. Sáo dotados de grande prestígio, de invisibilidade e de imortalidade. Os homens se relacionam com os encantados por meio de xamãs.

O mundo dos encantados é organizado a partir de redes de cooperação e de agressão vinculadas à estrutura de promessas, manifestações de doenças e curas que institui a relação entre os humanos e os sobre-humanos.

Os encantados são seres sobre-humanos. Todo encantado foi um humano que se transformou em um ser que habita o cosmos. Alguns homens, principalmente por suas condutas sociais, transformaram-se em seres sobre-humanos através do encantamento. Estes, em geral, praticavam açôes vinculadas à cura, havendo casos inclusive de religiosos, capelães e também Pankararu que se encantaram. 
De acordo com um relato do mito de surgimento dos encantados, durante um ritual em um terreiro, em um tempo de escassez, o cantador e sua esposa negam fumo ao comandante da dança e são destinados a se tornar imbu, para fornecer fruto o ano todo, e raposa por terem quebrado as regras de convívio social. Então, oito homens vão para a cachoeira de Itaparica e são transportados ao fundo das águas por uma peneira onde se transformam em encantados. É anunciado um mundo de fartura, repleto de canto, música, fumo e comida que pode ser compartilhado com os homens através de relaçôes de reciprocidades. Segundo Arruti (1996), os encantados seriam índios que descobriram o segredo de se encantar e alcançaram a imortalidade, universo este passível de ampliação. Depois de encantados, manifestar-se-iam através das "sementes" para seus "zeladores".

A indicação de potenciais xamãs é feita através da manifestação de doenças, de sonhos e do aparecimento recorrente de "sementes". Os encantados são herdados, preferencialmente, entre xamãs pertencentes à mesma família. A produção de novos encantados tende a acontecer em uma família que não participa da rede já instaurada de "zeladores de praiás", em geral aquelas mais dis-

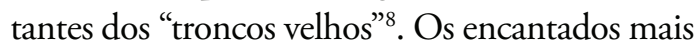
novos, cujos praiás foram "levantados" - termo empregado pelos Pankararu para se referir ao ritual em que se confeccionam as vestimentas dos praiás - recentemente, são vistos com ressalvas, em especial pelas famílias que são responsáveis por zelar pelos praiás mais antigos.

Os humanos que serão incumbidos do papel de xamã encontram uma pedra ou semente em forma de animal ou de gente; mesmo que a joguem fora, a pedra reaparece, sinalizando que esta pessoa foi indicada, por Deus, para "levantar um praia’".

Outra forma de se tornar um xamã está vinculada ao aparecimento recorrente de doenças em determinado indivíduo. Sua cura ocorrerá somente por meio de sessóes xamânicas em que os encantados revelam ao curador que aquele doente deverá se tornar "dono de praiâ". A aceitação desta incumbência, regida por regras e obrigaçóes, conduz a um acesso direto aos encantados.

Dessa forma, os encantados identificam os xamãs com os quais irão se relacionar, os quais serão os mediadores da relação entre os humanos e os sobre-humanos. Os novos xamãs serão submetidos a um período de iniciação. Este modelo garante a (re)produção de xamás e encantados, bem como a continuidade do sistema xamânico entre os Pankararu.

Os "zeladores de praiás" - também conhecidos como "donos de praia”" ou "pais de praia" - são especialistas encarregados de estabelecer a relação entre os humanos e os sobre-humanos. Estes são encarregados de "zelar", no sentido de cuidar, de tudo o que envolve os encantados que estão sob sua responsabilidade. Os encantados, através de sonhos, transmitem a seus "zeladores ou pais" seu nome - há diversos nomes de pássaros -, decoração da vestimenta, passos rituais que serão executados no terreiro, e seu toante - música de cada praiá. Os "zeladores de praiás" têm como atribuiçóes confeccionar as vestimentas dos praiás e oferecer fumo regularmente aos encantados.

De acordo com os Pankararu, os encantados habitam palácios localizados nas serras, morros e matas, lugares que fazem parte da geografia das aldeias. Os encantados, quando se manifestam por meio de praiás, utilizam os terreiros para a prática dos rituais. Cada terreiro está vinculado a determinado grupo de encantados e, consequentemente, seus "zeladores”. Não são todos os "zeladores de praiás" que dispóem de terreiros próprios. Aqueles que zelam apenas por um praiá ou que, em geral, possuem um encantado mais novo compóem o núcleo de lealdade de um xamã que zela por um grupo específico de praiás - "batalhão", no vocabulário 
pankararu. O grupo de lealdade é formado pelas redes de parentesco, compadrio e amizade, eixo onde se desenrolam as relaçóes de prestação e contraprestação.

Há mais de cinco dezenas de encantados cujos "zeladores" são Pankararu e residem nas aldeias em Pernambuco e São Paulo. O sistema de produção de encantados é dinâmico e está também atrelado ao crescimento do grupo, ao aumento dos núcleos familiares e à dispersão dos Pankararu em outras localidades e regiôes, movimento legítimo entre eles. $\mathrm{O}$ surgimento de novos encantados, embora visto com desconfiança, principalmente pelas famílias mais antigas, está em plena atividade, criando e reorganizando os núcleos de lealdade. $\mathrm{O}$ sistema xamânico atua como agente catalisador da história, incorporando e traduzindo novos eventos, experiências e pessoas que são agregadas aos Pankararu.

A Corrida do Imbu é composta por fases que são realizadas em determinados terreiros vinculados a encantados ligados ao "tronco velho". Essas fases são compostas por canto, música e dança ritual. Os "zeladores de praiás" escolhem alguns rapazes que irão dançar com seus praiás. Estes devem passar por um processo de iniciação que implica no cumprimento de obrigações, como abstinência sexual e defumação do corpo com banhos e fumaça. Outra maneira de dançar nos praiás é ser indicado por algum encantado em virtude de sofrer de alguma doença.

O sistema musical pankararu envolve todo o ritual. Toantes e torés, cantos rituais, são revelados pelos respectivos encantados em sonhos aos "zeladores ou pais dos encantados". Cada encantado tem um toante, que é um canto sagrado de evocação que facilita o acesso e estabelece um canal de comunicação com o mundo sobrenatural (Carneiro da Cunha, 1999). Os cantadores, vinculados aos terreiros, comandam a evolução das danças. Cada terreiro dis- póe de um estoque de cantadores selecionados a partir do núcleo de lealdade do "zelador de praia” daquele terreiro. Os cantadores podem ser preparados por outros cantadores ou por mensagens e ensinamentos que recebem pelos sonhos.

Uma parte importante da cerimônia são as refeições oferecidas aos encantados e a todos os participantes, vindo estabelecer um circuito de trocas entre o mundo visível e o invisível. O "zelador" do terreiro oferece o almoço aos praiás e aos demais participantes do ritual. Os praiás fazem suas refeiçóes, durante os rituais, em um local reservado denominado poró.

Nos terreiros os praiás executam sequências de coreografias que são repetidas exaustivamente. A composição das filas de praiás durante a movimentação no terreiro não é aleatória. Há uma hierarquia nessa distribuição, sendo o "dianteiro" - o primeiro da fila -, em geral, o "dono do terreiro" e comandante do rito; e o "traseiro", sempre um dos praiás de mais "força”, de preferência Cinta Vermelha", responsável pela proteção do grupo de possíveis agressóes de entidades sobre-humanas.

A Corrida do Imbu inicia-se quando encontram o primeiro imbu maduro. Organizam então, em terreiros determinados, a cerimônia conhecida como Flechamento do Imbu, geralmente entre os meses de outubro e dezembro. Aos praiás cabe flechar os imbus para depois disputarem um cabo de força - homens X homens, no Brejo dos Padres, e homens X praiás, na aldeia Serrinha - cujo resultado final define a sorte da colheita do ano.

A parte principal da Corrida do Imbu é composta pelos rituais Noite dos Passos, Queima do Cansanção, Imbuzada e Saída do Mestre Guia, que serão sucintamente desenvolvidas a seguir. Para visualizar as fases da Corrida do Imbu e a sequência de cortejos da Penitência que ocorrem entre fevereiro e março, segue um quadro sintético com o calendário do período: 
\begin{tabular}{l|l} 
DoIS ELOS DA MESMA CORRENTE & I 69
\end{tabular}

CALENDÁRIO PARCIAL DO SISTEMA RITUAL PANKARARU:

\begin{tabular}{|c|c|c|c|c|c|c|}
\hline \multicolumn{4}{|c|}{$\begin{array}{l}\text { CORRIDA DO IMBU } \\
\text { (Brejo dos Padres) }\end{array}$} & \multicolumn{3}{|c|}{$\begin{array}{c}\text { PENITÊNCIA } \\
\text { (Brejo dos Padres) }\end{array}$} \\
\hline $\begin{array}{l}\text { sequência } \\
\text { temporal }\end{array}$ & $\begin{array}{c}\text { noite } \\
\text { (sábado) }\end{array}$ & $\begin{array}{c}\text { dia } \\
\text { (domingo) }\end{array}$ & $\begin{array}{c}\text { noite } \\
\text { (domingo) }\end{array}$ & \multicolumn{2}{|c|}{ noite } & dia \\
\hline $\begin{array}{l}1^{\circ} \text { final de } \\
\text { semana } \\
\text { (Carnaval) }\end{array}$ & $\begin{array}{l}\text { Noite dos } \\
\text { Passos }\end{array}$ & $\begin{array}{l}\text { Queima do } \\
\text { Cansanção }\end{array}$ & & & & \\
\hline $\begin{array}{l}4^{\text {a }} \text { feira de } \\
\text { Cinzas }\end{array}$ & & & & \multicolumn{2}{|c|}{$\begin{array}{l}\text { Início da Penitência } \\
\text { (homens e mulheres) }\end{array}$} & \\
\hline 6a feira & & & & \multicolumn{2}{|l|}{ Penitência } & \\
\hline $\begin{array}{l}2^{\circ} \text { final de } \\
\text { semana }\end{array}$ & $\begin{array}{l}\text { Noite dos } \\
\text { Passos }\end{array}$ & $\begin{array}{l}\text { Queima do } \\
\text { Cansanção }\end{array}$ & & & & \\
\hline 4a feira & & & & \multicolumn{2}{|l|}{ Penitência } & \\
\hline $6^{\text {a feira }}$ & & & & \multicolumn{2}{|l|}{ Penitência } & \\
\hline $\begin{array}{l}3^{\circ} \text { final de } \\
\text { semana }\end{array}$ & $\begin{array}{l}\text { Noite dos } \\
\text { Passos }\end{array}$ & $\begin{array}{l}\text { Queima do } \\
\text { Cansanção }\end{array}$ & & & & \\
\hline $4^{\text {a }}$ feira & & & & \multicolumn{2}{|l|}{ Penitência } & \\
\hline $6^{\text {a feira }}$ & & & & \multicolumn{2}{|l|}{ Penitência } & \\
\hline $\begin{array}{l}4^{\circ} \text { final de } \\
\text { semana }\end{array}$ & $\begin{array}{l}\text { Noite dos } \\
\text { Passos }\end{array}$ & \begin{tabular}{|l|} 
Corrida do \\
Mocó ${ }^{\circ} /$ \\
Imbuzada \\
\end{tabular} & \begin{tabular}{|l|} 
Mestre Guia \\
(aldeia \\
Serrinha) \\
\end{tabular} & & & \\
\hline $4^{\mathrm{a}}$ feira & & & & \multicolumn{2}{|l|}{ Penitência } & \\
\hline $6^{a}$ feira & & & & \multicolumn{2}{|l|}{ Penitência } & \\
\hline \multicolumn{7}{|l|}{$\begin{array}{l}5^{\circ} \text { final de } \\
\text { semana }\end{array}$} \\
\hline $4^{\text {a }}$ feira & & & & \multicolumn{2}{|l|}{ Penitência } & \\
\hline $6^{\text {a feira }}$ & & & & \multicolumn{2}{|l|}{ Penitência } & \\
\hline \multicolumn{7}{|l|}{$\begin{array}{l}6^{\circ} \text { final de } \\
\text { semana }\end{array}$} \\
\hline $4^{\text {a }}$ feira & & & & \multicolumn{2}{|l|}{ Penitência } & \\
\hline $6^{\mathrm{a}}$ feira & & & & \multicolumn{2}{|l|}{ Penitência } & \\
\hline $\begin{array}{l}\text { 70 final de } \\
\text { semana } \\
\text { “Domingo } \\
\text { de Ramos" }\end{array}$ & & & & & & $\begin{array}{l}\text { Penitência } \\
\text { feminina } \\
\text { visita o } \\
\text { Cruzeiro }\end{array}$ \\
\hline \multirow{2}{*}{$3^{a}$ feira } & & & & Mulheres & Homens & \\
\hline & & & & Tapera & Não sai & \\
\hline $4^{\text {a }}$ feira Santa & & & & $\begin{array}{l}\text { lgreja Santa } \\
\text { Luzia }\end{array}$ & Tapera & \\
\hline \multirow{2}{*}{$5^{\mathrm{a}}$ feira Maior } & & & & \begin{tabular}{|l} 
Cardoso \\
(aldeia \\
Serrinha)
\end{tabular} & Cruzeiro & \\
\hline & & & & \multicolumn{2}{|c|}{$\begin{array}{l}\text { Encontro de penitentes ho- } \\
\text { mens e mulheres na frente } \\
\text { da Igreja Santo Antônio }\end{array}$} & \\
\hline \begin{tabular}{|l|} 
6a feira Santa \\
(morte do Judas)
\end{tabular} & & & & Cruzeiro & Cardoso & \\
\hline $\begin{array}{l}\text { Domingo de } \\
\text { Páscoa }\end{array}$ & & & & & & \\
\hline
\end{tabular}


Na Noite dos Passos, os praiás e as "moças"11 - dançadeiras das Noites dos Passos - dançam uma sequência fixa de cantos relacionados, principalmente, a animais.

Após a Noite dos Passos, no período diurno ocorre a Queima do Cansanção ${ }^{12}$. A sequência ritual ocorre em três terreiros. Nesta etapa do ritual, algumas moças - incluindo as dançadeiras da Noite dos Passos -, conhecidas como "botadoras de cesto", levam cestos com frutas, refrigerantes e doces que serâo oferecidos aos encantados em retribuição às promessas atendidas. As "botadoras de cesto" convidam pares do sexo masculino, responsáveis por providenciar os suprimentos da cesta, para as acompanharem na dança ritual. $\mathrm{O}$ casal pinta o corpo com uma tinta branca, a fim de preparar-se para a queima do cansanção.

Um cortejo com todos os participantes, conduzido pelas "moças" que estão oferecendo os cestos aos encantados, leva até o terreiro onde acontecerá a Queima do Cansanção - local diferente de onde ocorreu a Noite dos Passos -, momento em que homens e mulheres, dançando em círculo, tocam-se com galhos de cansanção. Os praiás não participam efetivamente do ato da queima com a urtiga. Cabe aos homens oferecer o sacrifício e a penitência aos encantados que, em contrapartida, ficam encarregados de protegê-los dos seres sobre-humanos que provocam a doença e o sofrimento e de garantir um mundo de fartura, saúde e bem-estar. Este é um momento de retribuição aos encantados pelo atendimento das promessas, principalmente aquelas referentes às curas de doenças.

Para finalizar a Corrida do Imbu no Brejo dos Padres, as "moças" e os "zeladores praiás" oferecem a Imbuzada - caldo preparado com imbu cozido, açúcar e água - aos encantados e aos humanos, em retribuição aos pedidos atendidos. Este momento fortalece uma rede de cooperação, instaurando um canal de comunicação e de reciprocidade entre os encantados e os consumidores da bebida, reforçando os grupos de lealdade, as redes de sociabilidade e a relação entre os humanos e os sobre-humanos.

Os "zeladores" do terreiro Poente, local onde acontece a Corrida do Imbu, exceto a etapa da Queima do Cansanção, têm como obrigação, após a Imbuzada, oferecer um pote com imbuzada ao Mestre Guia. O encantado Zé Fogaz, o principal do "batalhão" do terreiro Poente e o "dono" da Corrida do Imbu no Brejo dos Padres, tem como tarefa "entregar a tradição" e a "penitência do Imbu" ao Mestre Guia. Tal ato marca o término de suas obrigaçôes, a finalização da cerimônia no Brejo dos Padres e a "entrega" da Corrida do Imbu ao "comandante" dos encantados que é o "dono" daquele ritual.

Encerra-se a Corrida do Imbu com a aparição, à noite, em um terreiro na aldeia Serrinha, do Mestre Guia. Neste momento, há expressiva presença dos praiás. Por volta da meia noite, o "zelador do terreiro" e seus auxiliares servem a comida primeiramente para os praiás, que se alimentam no poró, e depois oferecem para os presentes. O Mestre Guia conduz o cortejo dos praiás no terreiro e benze os presentes.

Todas as fases do rito, exceto a Saída do Mestre Guia, são finalizadas com o Toré, ritual de caráter profano e sagrado, que pode ocorrer em espaços públicos ou privados. Como elemento de finalização dos ritos pankararu, o Toré encerra os momentos de comunicação e trocas com os seres sobre-humanos, propiciando a passagem para a vida cotidiana e a comunhão e celebração entre todos os presentes: personagens do rito, cantadores, praiás e espectadores, índios e não índios. $\mathrm{O}$ cantador se posiciona no centro do terreiro; toca o maracá - instrumento musical similar ao chocalho - conduzindo o ritmo das passadas de homens, mulheres e praiás que dançam em pares, em coreografia circular, ao redor do cantador. A prática do Toré mantém o laço com os seres 
sobre-humanos, reafirma valores e símbolos e fortalece o sentimento de identidade do grupo.

Conforme indicou V. Turner (1974) a partir da análise processual dos rituais, a ordem e a sequência das fases do rito são fundamentais para sua compreensão. Com relação à Corrida do Imbu, devemos estar atentos às partes e sua relação com o todo a fim de compreendermos as mensagens que o ritual está comunicando. A Corrida do Imbu explicita a hierarquia e as relações entre os membros da sociedade dos encantados, revitaliza a manutenção das relaçóes de reciprocidade com os seres do cosmos e as regras de sociabilidade estabelecidas através da relação entre os humanos e os seres sobre-humanos. Aos encantados são oferecidas dádivas e o sacrifício dos homens em retribuição à cooperação estabelecida entre os seres sobre-humanos e os humanos, mecanismo que está na base do sistema xamânico e que será reproduzido em rituais de menor expressão que são organizados, em geral, entre os membros dos grupos de lealdade em decorrência da realização de pedidos e do pagamento de promessas, conforme será abordado adiante.

A seguir, apresento a Penitência, ritual que também envolve os cantadores, tocadores, zeladoras de praiás e os especialistas vinculados diretamente aos encantados.

\section{A Penitência}

A Penitência ${ }^{13}$, com ocorrência entre os meses de fevereiro e março - único momento que segue a sequência ritual descrita a seguir -, é um ritual cíclico que ocorre de forma alternada com as fases da Corrida do Imbu. A Penitência não tem a expressividade, a dimensão e não ocorre em cerimônias de caráter público como a Corrida do Imbu, mas está bem presente entre os Pankararu.

Há um grupo de penitentes ${ }^{14}$ masculinos e femininos que promovem regras morais de conduta calcadas em elementos do catolicismo e que foram incorporadas ao sistema de crenças e práticas pankararu. A Penitência masculina foi ensinada pelos padres que atuavam no Brejo dos Padres, principalmente à família dos Barbosa, há mais de cem anos. A Penitência feminina foi organizada por Bárbara Oliveira, por influência de Madrinha Dodô, uma beata e penitente que percorria algumas cidades do interior nordestino. A Penitência feminina está ligada à Madrinha Dodô e ao messiânico Padrinho Pedro Batista da Silva - ambos falecidos. Pedro Batista é identificado à curas de doenças, adivinhações, pregações e indicação de conselhos.

Os penitentes pankararu realizam peregrinações noturnas às cruzes dos mortos, situadas nos caminhos das aldeias, em quintais das casas e no cemitério. A Penitência começa na Quartafeira de Cinzas - início da Quaresma, na tradição católica, compreendida entre Quarta-feira de Cinzas e Domingo de Páscoa - e estende-se até a Sexta-feira da Paixão, na Semana Santa, cujo término é na semana da Páscoa - festa anual católica que comemora a ressurreição de Cristo. A partir da Quarta-Feira de Cinzas, todas as sextas e quartas-feiras, à noite, os penitentes, agregados por gênero, cantam e rezam na Igreja de Santo Antônio - santo padroeiro dos Pankararu -, localizada no Brejo dos Padres, e partem para caminhadas em visita às cruzes dos mortos.

As mulheres não têm acesso à Penitência masculina, inclusive porque há a sessão da "disciplina”, na qual alguns homens se autoflagelam com elementos cortantes, conferindo um caráter sigiloso a esse cortejo ${ }^{15}$. $\mathrm{O}$ período e os dias em que acontecem são os mesmos ${ }^{16}$; bem como as regras de conduta e motivaçôes são similares na Penitência masculina e feminina. As mulheres sempre carregam a imagem de "Nossa Senhora da Boa Morte" e os homens, do "Nosso Senhor Morto". 
Este período da Penitência é encerrado com peregrinaçóes dos penitentes masculinos e femininos em visitas às cruzes dos mortos, durante quatro dias sequenciais, na última semana de realização do rito. Na passagem de Quinta para Sexta-feira Santa acontece o encontro dos penitentes masculinos e femininos em frente à Igreja de Santo Antônio, momento em que fica explícita a complementaridade entre os dois grupos. Estes percursos realizados pelos cortejos formam o desenho imaginário de uma cruz. Aí está a importância da análise processual e formal do ritual (V. Turner, 1974), pois o sentido está também em formar a cruz, agente central deste rito.

Há duas cruzes de madeira, com cerca de 1,5 $\mathrm{m}$ de altura, que ficam expostas no altar da Igreja de Santo Antônio, no Brejo dos Padres, e são artefatos que requerem especial dedicação dos Pankararu. Barcelos Neto (2004), entre os Wauja, estuda um complexo ritual em que homens e espíritos são personificados em flautas, panelas e máscaras. As coisas são apreendidas como pessoas e configuram índice de mediação entre os humanos e os sobre-humanos. De forma similar, entre os Pankararu, as cruzes são artefatos que operam a mediação da relação entre os humanos e os sobre-humanos e atuam como canal de comunicação para a efetivação da cura de doenças.

Dona Amélia Julião - uma das responsáveis pela Penitência feminina -, afirma que "a cruz é que nos sustenta”.

A cruz é tudo, é a dona do mundo. É quem sustenta nós, é que segura nós tudo, segura nossos pecados, nossas culpas. A cruz é tudo em nossa vida, é dona do mundo, carrega nossa vida, nossas culpas, nosso pecados. Ela está no mundo pra reunir tudo, apresentar Nosso Senhor a nossa vida, porque nós é por causa dela, ai de nós se não fosse ela. Nós deita com ela, levanta com ela, batiza com ela, casa com ela, morre com ela, tudo é a cruz. Então nós tem que zelar. A cruz é uma autoridade do mundo, se não quiser se benzer tem que levantar na hora que ela passa. $\mathrm{Na}$ igreja eu mudei muito, melhorei muito. Eu era muito nervosa, preocupada. Não podia ver uma pessoa correndo que achava que era uma briga, uma má notícia. E lá na igreja eu me ajoelhei nos pés da Santa Cruz, me entreguei a ela. Aí não ligo não, rezo meu rosário de noite e puxo meu sono, confio nela. (Amélia Julião, penitente, março de 2003)

As cruzes, tanto as de madeira dos penitentes como todas as demais, são um artefato de fundamental importância entre os Pankararu. Tornam-se objetos com dinâmica e poderes próprios, com prerrogativa de propiciar uma relação de cooperação entre os homens, e estão associadas aos mortos - seres que habitam o cosmos. Os locais onde foram enterrados os mortos estão sempre identificados com uma cruz, fincada no solo ou na sepultura. Estes recebem as rezas dos penitentes em peregrinação.

O canal de comunicação com os mortos é estabelecido pelos penitentes através de sonhos, visôes e rezas. Esta prerrogativa é dada aos penitentes que participam assiduamente dos cortejos e rezas. As mulheres responsáveis pela Penitência são especialistas que conduzem os processos de cura e de resolução dos problemas daqueles que proferiram promessas para a Santa Cruz. Para obter resultado devem também seguir determinado padrão de conduta, sobretudo moral, estabelecido aos Pankararu, como: não ingerir bebida alcoólica, não fumar e não usar roupas decotadas. Seguir essas orientaçóes repercute na "força" da reza e da cura através da Santa Cruz, e também, no poder visionário dos penitentes.

Quanto aos mortos, conta dona Amélia Juliâo que "nossa obrigação é de quem morre" e diz sentir-se feliz quando reza para os mortos.

No céu só estão os anjos e Nosso Senhor, os mortos vão para o lugar de acordo com a 
sentença que Deus der. Eles não ficam aqui vagando. Aparecem em sonho. Ficam nos cruzeiros, nas Igrejas, onde tiver a palavra de Deus ficam recebendo as rezas. Quando morrem, ficam com fogo nas costas. Os mortos devem ir para os Santos Cruzeiros fazer suas penitências. (Amélia Julião, penitente, março de 2003)

Os mortos são seres sobre-humanos que habitam o cosmos - residem nos cruzeiros fincados nas serras, nos caminhos das aldeias e nos quintais das casas que indicam locais de sepultamento - e estão em constante relaçáo com os humanos. Os mortos, segundo relato dos Pankararu, como extensão das obrigaçóes do mundo visível, continuam rezando nos cruzeiros a fim de cumprir penitência. É uma ação destinada aos cruzeiros, artefato-pessoa com capacidade de estabelecer redes de cooperação. No entanto, os mortos também adquirem a capacidade de promover redes de cooperação e de agressão. Os mortos não possuem diretamente a prerrogativa da cura, mas podem cooperar através de um conselho e atuar como espécie de auxiliares da Santa Cruz e dos encantados. Os humanos e os mortos precisam praticar a penitência e a reza, aqueles para receberem a cura de uma doença, enfim, a dádiva relacionada a algum pedido, e estes para colaborar e auxiliar com o oferecimento da dádiva àqueles que a solicitam.

Os mortos tem uns bons e uns ruins. Os bons procuram os pés dos montes pra fazer sua oração, sua prece. Quem trabalha pra Deus nesse mundo, quando morre leva a vida trabalhando para Deus, até o dia final quando morre, que Deus vai vim juizar. Deus vai vim um dia juizar nós, vai vim julgar. Nós estamos nessa fé que ele vai vim julgar nós, como no Credo em Deus Pai. Vai vim julgar os vivos e os mortos. (Amélia Julião, penitente, março 2003)
Os penitentes rezam pelos mortos e para todos os mortos. As promessas dirigidas aos penitentes pelos Pankararu são feitas à Santa Cruz e aos santos - entidades cultuadas pelos praticantes do catolicismo. As cruzes e os mortos são os elementos da "obrigação" dos penitentes. Ao final deste período ritual, oferecem a Penitência à Madrinha Dodô, ao Padrinho Pedro Batista e à Santa Cruz na cidade de Santa Brígida ${ }^{17}$, local de romaria por ser onde recebiam os peregrinos e onde estáo sepultados. A incorporação da Penitência pelos Pankararu permitiu a ampliação do seu sistema ritual e xamânico.

\section{Promessas e Curas}

Os Pankararu identificam que algumas doenças e seus processos de cura estão ligados ao sistema da Santa Cruz e aos encantados, que de forma semelhante são ativados por meio de mecanismos de promessas proferidas aos seres que habitam o mundo invisível. A relação dos homens com os seres sobrenaturais, por intermédio dos encantados ou da Santa Cruz, é estabelecida através de relaçóes de reciprocidade ancoradas na chave maussiana da dádiva.

As doenças são produzidas em decorrência de processos de agressóes e predaçóes proferidas pelos seres sobrenaturais. Quando acometidos por certas doenças, pelo risco iminente de morte, por alguma situação que gere intenso sofrimento ou por visôes perturbadoras, os Pankararu costumam fazer pedidos, comprometendo-se, através de promessas, com os encantados e/ou a Santa Cruz para o restabelecimento daquela pessoa ou para o desfecho satisfatório de determinado caso. A escolha do ente ao qual será dedicada a promessa, em geral, é feita por indicação manifestada em sonho ou pela seleção de um ser sobrenatural que se relaciona com um xamã do núcleo de lealdade do doente. 
Como interlocutores e mediadores do contato com os seres sobrenaturais e com a Santa Cruz estão os "donos de praiás", determinados penitentes e os rezadores. Os xamás são controladores dos poderes sobre-humanos que devem ser usados em benefício da sociedade. Os "donos de praiás", como mediadores entre os seres humanos e sobre-humanos, estão automaticamente nessa categoria de rezadores com capacidade de afastar a doença e, consequentemente, o sofrimento e a morte do paciente. São reconhecidos pelo grupo como figuras fundamentais nesse processo. Já os penitentes são os intermediários no processo de estabelecimento de relaçóes com a Santa Cruz, seus poderes e as entidades a ela vinculadas.

Há outra categoria que é a de rezadores ou curadores, a qual não é composta por "zeladores de praiás”, e cujos membros não participam necessariamente da Penitência. Estes trabalham com seres que alguns denominam guiasentidades sobrenaturais que não se encantaram, mas que podem se enquadrar na categoria de mortos, como Santos, Freis, Cosme e Damião, Divino Espírito Santo, Padrinho Pedro Batista e Madrinha Dodô, entre outros -, com os encantados e a Santa Cruz. Os curadores, em presença dos "pais de praiás", participam de "mesas de cura" - rituais noturnos, realizados em espaços privados, em que doente e curador ficam diante de uma esteira composta por artefatos rituais e praticam trabalhos voltados à cura de doentes. Também há curadores que incorporam os encantados, mas não os possuem, evocando-os, com a licença de seus zeladores, quando estáo benzendo ou em "mesas de cura".

A história de vida do xamã e o consequente histórico das relaçôes sociais estabelecidas pelo grupo estáo intimamente ligados às formas assumidas pelos entes do cosmos em seus sonhos e visões. Podemos, para o sistema xamânico pankararu, emprestar a noção de xamanismo mestiço, movimento que realiza a convergên- cia dos diferentes pontos de vista e atua como instituição de tradução identificado no baixo Urubamba e no Oiapoque (Peter Gow, 2001; Andrade, 2006).

Essas são classes de xamãs cuja vocação, em geral, é de nascença e se manifesta através de doenças recorrentes como dores de cabeça, angústias, desmaios, diarréias, visões do mundo invisível e de práticas como tentativas de suicídio que acometem os pacientes, em geral, desde a infância. No entanto, nem todos aqueles que adoecem serão indicados como potenciais xamás, característica que é sinalizada, entre outros fatores, pela recorrência da doença.

Os potenciais rezadores e curadores fatalmente serão acometidos pela doença, pois têm mais sensibilidade com relação ao mundo sobrenatural, capacidade ainda desconhecida e não controlada. Encontram-se vulneráveis às doenças por estarem de "corpo aberto" - expressão que indica a condição em que a pessoa está suscetível às agressóes dos seres sobre-humanos. Neste caso, procuram os cantadores de seu grupo de lealdade para tratamento, momento em que são avisados pelos seres sobrehumanos sobre sua especialidade xamânica. $\mathrm{O}$ paciente passa então por um processo de purificação e iniciação que o habilita às práticas xamânicas. Os seres sobre-humanos abandonam o xamã caso este não cumpra suas obrigações vinculadas aos entes do cosmos.

As doenças são provocadas por encantados vinculados às redes de agressão, alguns mortos, guias ou entidades maléficas que deixam em estado de possessão os pacientes. Adoecer significa ter seu princípio vital "raptado" pelos seres sobre-humanos. É instituída uma relação de predação. Os seres predadores podem ser enviados pelos homens ou podem se apossar do potencial doente caso ele transite em encruzilhada, riacho ou nascente de rio - lugares habitados pelos entes do cosmos - de "corpo aberto", termo empregado pelos Pankararu. 
Os Pankararu não recomendam ir ao terreiro, e tampouco passar em encruzilhada, sem camiseta; é indicado, especialmente aos rezadores, dormir com camisa a fim de evitar ficar de "corpo aberto". $\mathrm{Na}$ condição em que não foram cumpridas as regras de conduta - não passar em locais proibidos em determinados horários, estar em dia com as prestaçôes destinadas aos seres sobre-humanos, etc -, a pessoa está mais propensa a ser "flechada" - expressão utilizada pelos Pankararu quando alguém está possuído por entidade agressora.

Alguns seres sobre-humanos estão ligados a redes de cooperação e outros de agressão e predação; e há xamãs, independente da categoria a que pertencem, podendo ser ou não Pankararu, que acionam forças agressoras encontradas em nascentes, riachos, mata, mas que também podem vir de fora da aldeia.

As doenças, quando provenientes de contatos com seres sobrenaturais, são identificadas pelos xamãs. Estes convocam na rede de cooperação os encantados, a Santa Cruz, e/ou os guias para realizar a cura, conforme a categoria a que pertence o xamã. A cura, muitas vezes, é revelada em sonho, momento em que os xamâs recebem a indicação de que a causa da doença foi uma "flechada", o que significa que o princípio vital do paciente está sendo controlado, mesmo que não integralmente, pelos seres sobre-humanos.

Adoecer é criar uma relação com o mundo sobrenatural e com o mundo da sociabilidade e, ao mesmo tempo, criar uma intersecção entre esses dois espaços, mecanismo que ocorre entre os Wauja (Barcelos Neto, 2004), mas que pode ser pensado com relação aos Pankararu.

O paciente passa então por tratamento em sessões rituais. Os xamãs - independentemente de sua filiação ou "corrente" - atuam como mediadores da comunicação com o mundo invisível e transmitem as fórmulas e receitas indicadas aos pacientes pelos encantados, Santa
Cruz, mortos ou outros entes do cosmos. Segundo Tambiah (1985), o oficiante tem a permissão do cliente para fazer uma cura e avisar sobre um perigo eminente. $\mathrm{O}$ objetivo é fazer uma troca entre o oculto e o humano tendo como mediador o oficiante, que produz uma conjunção em andamento na existência social.

Há procedimentos e tratamentos que levam à cura de doenças. As agressóes dos seres sobrenaturais e a realização de sessóes de cura fazem parte do cotidiano dos Pankararu. As curas, de maneira geral, ocorrem na esfera privada e mobilizam o núcleo de lealdade do "pai de praia”, rezador ou curador. As curas podem ser efetivadas por benzimentos ou Mesadas dedicadas aos encantados, à Santa Cruz ou aos guias. Estas acontecem em "salóes de trabalho" - espaço organizado em um cômodo da casa dos rezadores. As Mesadas, destinadas tanto aos trabalhos de cura quanto aos pagamentos de promessas, são práticas rituais conduzidas por xamás. Cabe ao doente oferecer comida, bebida e fumo aos humanos e não humanos.

A repetição do rito de cura, geralmente três vezes, contribui para sua eficácia. Segundo Leach (1979) e Tambiah (1985), a repetição e a redundância produzem a intensificação do significado e perpetuam os conhecimentos que estão condensados.

A regularidade da prática dos ritos de cura, benzimentos e "mesas" confere prestígio ao especialista, podendo acarretar o aumento do seu núcleo de lealdade e, consequentemente, intensificar sua esfera de poder no âmbito das relaçôes entre os homens. Ao receber a dádiva, a família do doente se organiza para "pagar" a promessa, sob risco de acontecer algo grave no caso de não cumprimento da mesma.

Os homens em posição de devedores em decorrência de alguma promessa ainda não "paga” pela cura de uma doença ou por ter sido aplacado seu sofrimento organizam-se a partir do núcleo familiar ou do grupo de lealdade 
para estar em dia com os seres sobrenaturais. Os Pankararu retribuem o pedido atendido com o pagamento de promessas através de rituais realizados para os encantados, a Santa Cruz e entidades auxiliares. Os ritos de curas e de pagamentos de promessas são cerimônias realizadas em todos os períodos do ano e reúnem, em geral, o núcleo de lealdade do xamã, do exenfermo e do pagador de promessas.

O maior ou menor prestígio dos "zeladores de praiás" e rezadores, fundamentado na eficácia do cumprimento de sua missão, confere mais ou menos poder ao oficiante, por congregar um maior ou menor número de enfermos que o convocam. O trânsito pelos terreiros e pelos “salóes de cura” está vinculado às relações sociais instituídas e ao prestígio dos xamãs. Frequentam-se determinados terreiros também por haver laços de parentesco, compadrio, políticos e de amizade. Essa é a base da composição dos grupos de lealdade que dinamicamente vão se reorganizando e atuando em diversas esferas da vida social.

Quando fazem promessas aos encantados, os "pagamentos" são efetuados através de Três Rodas, Queima do Cansanção, Menino do Rancho - no caso de meninos - e Prato ${ }^{8}$, ritos realizados em terreiros em presença dos praiás; ou oferecimento de Garapa, rito que ocorre em âmbito privado e conta com a participação de parentes e amigos do pagador da promessa, além dos auxiliares do rezador e do "zelador de praia”. A Garapa ocorre na casa de rezadores, de "pais de praiás" ou daqueles que estão promovendo o pagamento da promessa em "salóes de trabalho”. Em todos esses rituais são oferecidas comidas e bebidas aos seres sobrenaturais e aos homens.

As curas, quando praticadas através de pedidos realizados à Santa Cruz, são retribuídas em "Mesadas" - cerimônias em que ocorre a evocação dos seres sobre-humanos e é oferecida comida e bebida aos penitentes. $\mathrm{O}$ ex-enfermo, após sua promessa ter sido atendida, amarra uma fita colorida na cruz dos penitentes, masculinos ou femininos, dependendo de a quem endereçou o pedido.

Os ritos relacionados ao pagamento de promessas são organizados em fases: preparação para o estabelecimento do contato com os seres sobrenaturais, oferecimento pelos ex-enfermos ou seus familiares de comidas, bebidas e fumo aos entes do cosmos e aos homens, e fechamento do ritual. A troca estabelecida através do oferecimento de comidas, bebidas e fumo é recorrente em todos os rituais, vindo a concretizar o pagamento da promessa e a relaçáo de reciprocidade entre os humanos e os seres sobre-humanos.

Quando os seres sobrenaturais atendem aos pedidos e promessas dos homens, instala-se uma instância onde há a obrigatoriedade da retribuição. Os homens, através da prática de ritos e da oferta de comida e bebida, tanto na corrente da Santa Cruz como na corrente dos encantados, quitam a "dívida" com os seres sobre-humanos. A reciprocidade e as trocas instauram um mundo de cooperação entre os humanos e os sobre-humanos. Esse vínculo é necessário por existir uma modalidade de agressão e violência direcionada aos homens - proveniente dos seres maléficos - que somente essa rede de cooperação pode anular e combater.

\section{Consideraçóes finais: as duas correntes pankararu}

A maioria dos autores (Hernãndez Días, 1983; Nascimento, 1994; Oliveira Filho, 1993a, 1993b, 1998; Arruti, 1999; Barreto Filho, 1992, 1999; Andrade, 2002; entre outros) que realizaram estudos entre os índios no Nordeste brasileiro abordou principalmente questóes ligadas à temática da etnicidade, da emergência das identidades e das trocas rituais 
interétnicas. Neste trabalho enfocamos o sistema ritual pankararu e as relaçóes entre os seres humanos e sobre-humanos.

Privilegiei uma análise que incorpora a recriação do sistema ritual, a partir de categorias definidas a priori, para dar conta da dinâmica social e da atualização da experiência, uma vez que está aberta aos eventos e à história.

O complexo ritual Pankararu pode ser pensado como unificador, constituinte da própria "sociedade" pankararu, nos termos propostos por E. Durkheim ([1996]2000), por ser uma instituição fundamental para a compreensão das relaçóes estabelecidas entre o grupo.

A Corrida do Imbu e a Penitência são rituais cíclicos, com práticas intercaladas em uma sequência temporal, vinculados a seres que habitam o mundo invisível. Dada a importância da análise processual e formal, conforme proposta de V. Turner (1974) e de Van Gennep (1998) - embora enfoquem o sistema de posiçóes na estrutura social -, observa-se uma alternância combinatória entre estes ritos, que instituem a relação dos homens com os seres sobre-humanos.

Os encantados, a Santa Cruz e os mortos ativam redes de cooperação de agressão na relação com os homens. Os Pankararu estão sempre suscetíveis à manifestação de doenças provocadas por seres sobrenaturais maléficos - não os seres sob as ordens do Mestre Guia e, tampouco, aqueles vinculados à Santa Cruz, mas seres que também habitam o cosmos e que fazem parte de uma rede de agressão. A vulnerabilidade dos homens está diretamente ligada ao não cumprimento de regras morais de conduta estabelecidas socialmente e à passagem dos homens, sob determinadas condições, por locais habitados pelos seres sobre-humanos, como as serras e as fontes d'água.

Acometidos por certas doenças, os homens recorrem a rezadores ou curadores, vinculados à corrente dos encantados ou da Santa Cruz.
Trata-se de um sistema de crenças e práticas com duas variantes, as quais apresentam estruturas, elementos e códigos similares. Em ambas as "correntes", os homens entram em contato com os seres sobre-humanos e participam de redes de cooperação e de agressão. Este mecanismo é acionado por meio de sonhos propiciatórios e em rituais - ritos de calendário, ritos de cura e ritos de pagamento de promessas.

Para combater os efeitos dessa guerra xamânica importa mais o prestígio do curador do que a identidade do agressor. A complexa teia de relaçóes sociais pankararu colabora para diluir a esfera de acusação entre os núcleos de lealdade, entre outros grupos indígenas ou mesmo entre os não índios.

A efetivação da cura somente é possível através da cooperação dos seres e entidades sobrenaturais, dinâmica que alimenta a produção de novos ciclos de prestaçóes. Os homens, após passarem pelos rituais de cura, enfim, após suas promessas e pedidos aos seres sobrenaturais terem sido atendidos, devem retribuir, em especial, aos encantados e à Santa Cruz. Nos ritos de pagamento de promessas os homens oferecem comida e bebida aos sobre-humanos e aos humanos. A modalidade do rito acionada está relacionada à gravidade da doença e à rede social na qual está inserida o doente.

Dona Amélia Julião relata que após ter começado a frequentar a igreja passou seu nervoso e recorda também que quando seu filho estava muito doente, "não dizia coisa com coisa”, então o levou para uma consulta com o "Padrinho Pedro Batista", que recomendou um tratamento que o curou. Em paralelo, acessa o sistema dos encantados. Conclui então que em casos de doenças "o remédio não é de médico, é na corrente da Santa Cruz e dos encantados".

A lógica pankararu absorve e recria os sistemas de representação, cuja combinatória expressa o complexo ritual pankararu. A incorporação da história e dos eventos pelos 
Pankararu permite a coexistência de variaçóes rituais que seguem um modelo similar de relacionamento com o mundo invisível, vindo a ampliar as formas de contato entre os homens e os seres sobre-humanos e a colaborar com a busca de respostas a novas situaçóes.

$\mathrm{Na}$ Corrida do Imbu e na Penitência, de maneira redundante, são destacados elementos e formas de acesso que estão em jogo para a concretização e efetivação da mediação entre o mundo dos humanos e dos seres sobrehumanos. A relação entre esses dois mundos é constantemente ativada por meio das práticas rituais. As relaçóes de troca e cooperação entre os humanos e os seres invisíveis são constituídas por relaçóes de reciprocidade que estabelecem o equilíbrio e o bem-estar social entre os Pankararu.

Há convergência de fluxos (Hannerz, 1997), a qual podemos traduzir pela aproximação entre as "duas correntes": os sistemas representados pela Corrida do Imbu e Penitência. Mesmo sendo desigual o equilíbrio entre os fluxos, com suas perdas e inovações, do ponto de vista cultural e social, é estabelecido um continuum aberto à diversidade.

As transformaçôes culturais decorrentes dos encontros entre as alteridades constituem formas de continuidades e de reprodução social, pois os grupos não são definidos por categorias culturais, mas por dinâmicas de interação. As sociedades ameríndias são produtos da história e têm capacidade de desenvolver estratégias de resistência e adaptação (Boccara, 2001).

O sistema xamânico e o complexo ritual pankararu estão abertos a absorver novos elementos e estão em constante processo de transformação e (re)elaboração, movimento fundamental para a perpetuação dessa sociedade que está constantemente se reinventando.
Two links of the same chain: the Corrida do Imbu and Penitência rituals among the Pankararu

abstract This article intends to contribute to the understanding of the Pankararu ritual system by focusing especially on "Corrida do Imbu" and "Penitência", which are cyclic rituals conducted simultaneously. This study explores the relationship between humans and super-humans, the system of reciprocity, and the network of cooperation and aggression present in this context. The mechanisms of communication and the connections established with the supernatural world - based on the system of promises and requests and concerning mainly the cure of illnesses - are daily elements of mediation in this relationship. The Pankararu are located in the São Francisco river region, in the state of Pernambuco, northeastern Brazil, and in the Greater Sao Paulo area, southeastern Brazil. Migration has occurred since the 1950s. The Pankararu have been classed as accultured and have gone through forced contact, intermarriage with other groups and loss of their native language.

keywords Ritual. Indigenous people from northeastern Brazil. Cosmology. Pankararu. Indigenous ethnology.

\section{Notas}

Este artigo é uma versão resumida e revisada da etnografia apresentada na dissertação de mestrado em antropologia social defendida na Universidade de São Paulo - USP, em março de 2006, com apoio da CAPES. Para a realização desse trabalho foi feita pesquisa de campo entre os Pankararu que estão nas aldeias em Pernambuco, principalmente no Brejo dos Padres e na Serrinha, entre os meses de fevereiro e abril de 1999 e de 2003, e no Real Parque, em São Paulo, entre junho de 1996 e de 1997 - Pesquisa de Iniciação Científica, Ciências Sociais/USP, realizada com bolsa concedida pela FAPESP - e maio de 2003.

2 Na dissertação de mestrado Dois elos da mesma corrente: uma etnografia da Corrida do Imbu e da Penitência entre os Pankararu indiquei fevereiro e março 
como o período da realizaçâo da Corrida do Imbu e da Penitência, pois usei como referência o ano 2003, quando realizei a pesquisa de campo. No entanto, este período varia de acordo com a data do Carnaval, festa profana anual, com data móvel, que antecede a Quaresma - para os católicos, tempo de penitência, que vai da Quarta-feira de Cinzas até o domingo de Páscoa. Esta época marca o início das chuvas, importante indicador de plantio e colheita.

Os primeiros migrantes pankararu foram trabalhar na construçáo de estradas de ferro no interior do Estado de São Paulo na década de 1950.

4 A distribuição geográfica e os dados populacionais apresentados foram coletados no ano de 2003, em decorrência do levantamento de informaçóes para a elaboração da dissertação de mestrado.

5 Família das Anacardiaceae. Nomes: umbu, imbu, ambu. Origem: Nordeste brasileiro. Árvore de pequeno porte com frutificação, em geral, entre dezembro e março.

6 O bioma caatinga é o principal ecossistema existente na Regiāo Nordeste brasileira. Estende-se pelo domínio de climas semi-áridos. A ocorrência de secas estacionais e periódicas estabelece regimes intermitentes aos rios e deixa a vegetaçáo sem folhas. A folhagem das plantas volta a brotar e fica verde nos curtos períodos de chuva.

7 Entrudo, na cultura ocidental, é caracterizado por uma festa popular de tradição portuguesa que se desenvolvia nas ilhas africanas de Cabo Verde e da Madeira precedendo a Quaresma. A chegada do Entrudo no Brasil, uma das principais raízes do Carnaval, ocorreu no início da colonização portuguesa. Apesar de constantes proibiçôes, a festa era muito apreciada pela populaçáo. O Entrudo era praticado na rua e sua principal característica era a agressão mútua.

8 Os "troncos velhos", "[...] reservas de memória, de cultura e de religiosidade [...]" são representados pelas famílias consideradas "principais"; já as famílias "misturadas" são consideradas "mais frágeis com relação às heranças dos antepassados” (Arruti, 1995, p. 77).

9 Cinta Vermelha é um praiá identificado ao "tronco velho". É muito respeitado pelos Pankararu.

10 Mamífero roedor usado como alimento.

11 Algumas moças que dançam com os praiás na "Noite dos Passos" - fase da Corrida do Imbu - têm suas posições fixas e permanentes; outras são convidadas pelo cantador na abertura do terreiro - que ocorre um final de semana antes do "início" da Corrida do Imbu. Ao aceitar o convite, firmam o compromisso de participar das quatro noites.

12 Arbusto das urticáceas, com pêlos urticantes. Provoca coceira e irritaçáo na pele.

13 Este texto trata das manifestaçóes dos penitentes atreladas a um período determinado do ano, cuja etapa culmina com uma peregrinação à Santa Brígida (ver nota 17). Privilegiar este momento não significa desconsiderar demais peregrinaçóes dos penitentes e sua participação em outras comemoraçōes, mas enfatizar aspectos estruturais que podem ser relacionados à Corrida do Imbu e à cosmologia pankararu.

14 Os penitentes formam irmandades nas comunidades $\mathrm{da}$ região, principalmente rurais, ligadas ao catolicismo.

15 Neste trabalho, dedico-me especialmente à Penitência feminina, pois, por questáo de gênero, não tive acesso à Penitência masculina.

16 Ver o "Calendário parcial do sistema ritual pankararu".

17 Na cidade de Santa Brígida - BA, situada a cerca de $40 \mathrm{~km}$ do Brejo dos Padres, tem um memorial que foi a residência de Pedro Batista e Madrinha Dodô. Atualmente, há um santuário com imagem de Pedro Batista, Madrinha Dodô e Padre Cícero e é local de romaria.

18 Este rito também pode ser realizado nas casas, sem a presença de praiás.

\section{Referências bibliográficas}

ANDRADE, Ugo Maia. Um Rio de Histórias. A formação da alteridade Tumbalalá e a rede de trocas do submédio São Francisco. 2002. Dissertação (Mestrado) - Faculdade de Filosofia, Letras e Ciências Humanas, Universidade de São Paulo, São Paulo, 2002.

$O$ real que não é visto. Xamanismo e relação no Baixo Oiapoque (AP). 2006. Tese (Doutorado) - Faculdade de Filosofia, Letras e Ciências Humanas, Universidade de São Paulo, São Paulo, 2006.

ARRUTI, José M.P.A. Morte e Vida do Nordeste Indígena: a Emergência Étnica como Fenômeno Histórico Regional. Estudos Históricos, v.8, n.15, 1995, p.57-94. O Reencantamento do Mundo: Trama histórica e Arranjos Territoriais Pankararu. PPGAS do Museu Nacional/UFRJ. 1996.

A árvore Pankararu: fluxos e metáforas 
da emergência étnica no sertão do São Francisco. In: OLIVEIRA, João P. de (Org.) A viagem da volta: etnicidade, politica e reelaboração cultural no Nordeste indigena. Rio de Janeiro: Contra Capa Livraria, p.229-277, 1999.

BARCELOS NETO, Aristóteles. Apapaatai: rituais de máscaras no Alto Xingu. 2004. Tese (Doutorado), Faculdade de Filosofia, Letras e Ciências Humanas, Universidade de São Paulo, São Paulo, 2004.

BARRETTO FILHO, Henyo Trindade. Tapebas, Tapebanos e Pernas-de-Pau: etnogênese como processo social e luta simbólica. 1992. Dissertação (Mestrado) - Museu Nacional, Universidade Federal do Rio de Janeiro, 1992.

. Invenção ou renascimento? Gênese de uma sociedade indígena contemporânea no Nordeste. In: OLIVEIRA, João P. de (Org.). A viagem da volta: etnicidade, politica e reelaboração cultural no Nordeste indigena. Rio de Janeiro: Contra Capa Livraria, p.91136, 1999.

BOCCARA, Guillaume. Mundos Nuevos en las Fronteras del Nuevo Mundo: Relectura de los Processos Coloniales de Etnogénesis, Etnificacion y Mestizaje en Tempos de Globalizacion. Mundo Nuevo, Nuevos Mundos. Paris: CERMA/CNRS-EHESS, 2001.

CARNEIRO DA CUNHA, Maximiliano. A música encantada Pankararu. 1999. Dissertação (Mestrado) - Programa de Pós-Graduação em Antropologia Cultural da Universidade Federal de Pernambuco, 1999.

DURKHEIM, Émile. As formas elementares da vida religiosa: o sistema totêmico na Austrália. 2 ed. São Paulo, Martins Fontes, 2000.

GOW, Peter. An Amazonian myth and its history. Oxford: Oxford University Press, 2001.

HANNERZ, Ulf. Fluxos, fronteiras, híbridos, palavraschave da antropologia transnacional. Mana, v.3, n.1, p.7-39, 1997.
HERNÃNDEZ DÍAZ, Jorge. Os Fulniô: relaçôes interétnicas e de classe em Águas Belas.1993. Dissertacáo (Mestrado) - Departamento de Antropologia, Universidade de Brasília, 1983.

LEACH, Edmund R. Ritualization in Man in Relation to Conceptual and Social Development. In: LESSA, W. e VOGT, E.(orgs.). Reader in Comparative Religion: An Anthropological Approach. Harper \& Row Publishers, 1979.

LÉVI-STRAUSS, Claude. O Feiticeiro e sua Magia. In: . Antropologia Estrutural. Rio de Janeiro: Tempo Brasileiro, 1975.

NASCIMENTO. Marco Tromboni de S.N. O Tronco da Jurema. Ritual e etnicidade entre os povos indigenas do nordeste - o caso Kiriri. 1994. Dissertação (Mestrado). Faculdade de Filosofia e Ciencias Humanas, Universidade Federal da Bahia, Salvador, 1994.

OLIVEIRA FILHO, João Pacheco de. 'A viagem da volta' reelaboração cultural e horizonte político dos povos indígenas no nordeste. In: Atlas das Terras Indígenas do Nordeste. PETI, Museu Nacional. 1993a . Fronteiras étnicas e identidades emergentes. Revista Tempo e Presença, n. 270, p., 1993 b. . Uma etnologia dos 'indios misturados?? Situação colonial, territorialização e fluxos culturais. Rio de Janeiro, Mana, v. 4, n.1, p.44-77, 1998.

RIBEIRO, Rosemary Machado. O Mundo Encantado Pankararu. 1992. Dissertação (Mestrado) -Universidade Federal de Pernambuco, 1992.

TAMBIAH, Stanley J. Culture, Thought, and Social Action: An Anthropological Perspective. Harvard University Press, Cambridge, Massachussetts, and London, England. 1985.

TURNER, Victor W. O Processo Ritual: estrutura e antiestrutura. Petrópolis: Ed. Vozes. 1974.

VAN GENNEP, Arnold. Os Ritos de Passagem. Petrópolis: Editora Vozes. 1978.

autora

Priscila Matta

Mestre em Antropologia Social PPGAS/USP

Recebido em 25/03/2009

Aceito para publicação em 06/11/2009 